\title{
POPULASI BAKTERI ASAM LAKTAT PADA BUDIDAYA IKAN NILA YANG DIBERI PAKAN FERMENTASI LIMBAH PERTANIAN DENGAN SUPLEMEN ENCENG GONDOK DAN PROBIOTIK
}

\author{
ANDhika Agus SETyaWAN, SuKanto, ENDANG Widyastuti
}

Fakultas Biologi, Universitas Jenderal Soedirman, Jalan dr. Suparno 63 Purwokerto 53122

A B S T R A C T

The aim of this study were to determine the effect of fermented agricultural wastes feeding with supplement of water hyacinth and MEP+ probiotic towards the increasing population of intestinal Lactid Acid Bacteria (LAB) in Tilapia and to know the highest population of lactic acid bacteria after fermented agricultural waste feeding with water hyacinth supplements and $\mathrm{MEP}^{+}$probiotic. Independent variable in this study was fermented feed with the addition of different water hyacinth and MEP+ probiotics. The experimental study was continued using completely randomized design (CRD). The dependent variable in this study was the number density of Lactobacillus bacteria in the gut of Tilapia. The main parameters measured were the number of LAB. Proponent parameters were namely Tilapia weight gain, physical and chemical conditions of the water. The results showed that feeding fermentative effected in increasing the population of lactic acid bacteria in the gut of Tilapia. Fermentative feed supplement agricultural waste with water hyacinth as much as $10 \%$ and MEP+ probiotic was the best treatment with LAB population density in Tilapia intestine with the average of $5.85 \times 10^{6} \mathrm{CFU} / \mathrm{g}$.

KEY WORDS: lactic acid bacteria, probiotics MEP+, fermentative feed, water hyacinth

Penulis korespondensi: ANDHIKA AGUS SETYAWAN | email: dhikaaugust@gmail.com

\section{PENDAHULUAN}

Bakteri asam laktat (BAL) didefinisikan sebagai suatu kelompok bakteri gram positif, tidak menghasilkan spora, berbentuk bulat atau batang yang memproduksi asam laktat sebagai produk akhir metabolik utama selama fermentasi karbohidrat (Pato, 2003) Bakteri asam laktat banyak digunakan sebagai probiotik, bermanfaat untuk menjaga keseimbangan mikrobiota saluran cerna.

Probiotik adalah suplementasi sel mikroba utuh (tidak harus hidup) atau komponen sel mikroba pada pakan atau lingkungan hidupnya yang menguntungkan bagi inangnya (Irianto, 2003). Prinsip dasar kerja probiotik adalah pemanfaatan kemampuan mikroorganisme dalam memecah atau menguraikan rantai panjang karbohidrat, protein dan lemak yang menyusun pakan yang diberikan.

Mikroba Efektif Produktif Plus ( $\left.\mathrm{MEP}^{+}\right)$merupakan probiotik produk program IbIKK (Iptek bagi Inovasi dan Kreativitas Kampus) Universitas Jenderal Soedirman (Unsoed) yang di produksi Laboratorium Mikrobiologi Fakultas Biologi Unsoed, berupa kultur campuran spesies indigenous mikroba Gram positif non patogen yang bersifat amilolitik dan selulolitik. (Sukanto dan Sutardi, 2008).

Probiotik pada budidaya ikan dapat diaplikasikan pada pakan ikan. Ikan nila merupakan salah satu komoditas ikan air tawar yang mendapat perhatian besar oleh pelaku budidaya ikan dalam kaitannya dengan usaha pemenuhan kebutuhan protein. Hal ini dikarenakan ikan nila memiliki sifat-sifat yang menguntungkan, yaitu mudah berkembang-biak, tumbuh cepat, dagingnya tebal dan kompak, toleran terhadap lingkungan yang kurang baik, serta mempunyai respon yang luas terhadap pakan (Yulianti, et al., 2003).
Faktor kunci penting yang menentukan keberhasilan budidaya ikan secara intensif adalah menyediakan pakan dalam jumlah yang cukup dan bernutrisi sesuai dengan ikan yang dibudidayakan. Biaya budidaya perikanan yang dikeluarkan untuk pengadaan pakan bagi organisme yang dibudidayakan dapat mencapai $50 \%$ dari biaya produksi keseluruhan (Bautista, 1981).

Proses fermentasi pakan merupakan salah satu teknologi meningkatkan protein bahan baku dari limbah. Melalui proses fermentasi, akan didapatkan kandungan protein yang lebih tinggi dari sebelum difermentasi sehingga dapat mengurangi pemakaian tepung ikan yang mahal harganya.

Enceng gondok mengandung protein kasar $40 \%$. Tiga perempat (3/4) merupakan protein murni, dan nilai biologinya berada diantara kedelai dan air susu (Marlina dan Askar, 2001). Tingginya kandungan protein enceng gondok, memungkinkan digunakan sebagai pakan.

Penelitian ini bertujuan untuk mengetahui pengaruh pemberian pakan fermentasi limbah pertanian dengan suplemen enceng gondok dan probiotik MEP+ terhadap peningkatan populasi BAL pada usus ikan Nila dan mengetahui populasi bakteri asam laktat paling tinggi pada pemberian pakan fermantatif limbah pertanian dengan suplemen enceng gondok dan probiotik MEP+.

\section{METODE}

Penelitian ini dilakukan di PB Soedirman Banjarnegara dan Laboratorium Mikrobiologi Fakultas Biologi Unsoed pada bulan juni 2012 sampai dengan september tahun 2012

Bahan yang digunakan dalam penelitian ini adalah ikan nila, agar, media selektif MRSA akuades, alkohol 70\%, spirtus, pakan fermentasi (bahan baku: tepung enceng gondok, dedak, bungkil kelapa, ampas tahu, tepung ikan, $\mathrm{MEP}^{+}$, silage $\mathrm{MEP}^{++}$, dan tepung kanji), pakan komersial. Alat 
yang digunakan adalah ice box, autoklaf, Erlenmeyer, batang pengaduk, kompor gas, cawan petri, tabung reaksi, rak tabung reaksi, pembakar spiritus, korek api, sprayer, alumunium foil, mikropipet ukuran $1 \mathrm{~mL}$ dan $0,1 \mathrm{~mL}$, tip ukuran $1 \mathrm{~mL}$ (blue tip) dan 0,1 mL (yellow tip), drugalsky, wrapping, plastik, tissue, inkubator, kamera digital.

Metode yang digunakan dalam penelitian yaitu metode eksperimental menggunakaan Rancangan Acak Lengkap (RAL), dengan 5 perlakuan dan masing-masing dengan 4 kali ulangan. Perlakuan yang dicobakan adalah budidaya ikan nila pada keramba jaring apung dengan pemberian $\mathrm{MEP}^{+}$pada pakan fermentasi dengan kandungan suplemen enceng gondok (A) $0 \%$; (B) $5 \%$; (C) $10 \%$; (D) $15 \%$ dan (E) pemberian pakan komersial tanpa penambahan $\mathrm{MEP}^{+}$. Variabel yang diamati dalam penelitian adalah variabel bebas dan variabel tergantung. Variabel bebas meliputi pakan fermentasi dengan penambahan enceng gondok yang berbeda dan probiotik $\mathrm{MEP}^{+}$. Variabel tergantung dalam penelitian ini adalah jumlah kepadatan bakteri asam laktat di usus ikan nila. Parameter utama yang diamati adalah kepadatan bakteri asam laktat pada usus ikan, serta parameter pendukung berupa pertambahan bobot ikan Nila serta kondisi fisika dan kimia air. Parameter fisika berupa pengukuran suhu, dan parameter kimia berupa pengukuran $\mathrm{pH}$, pengukuran oksigen terlarut (DO), dan pengukuran amoniak $\left(\mathrm{NH}_{3}\right)$. Untuk mengetahui pengaruh perlakuan digunakan analisis ragam atau uji $\mathrm{F}$ dan dilanjutkan dengan Uji Beda Nyata Terkecil (BNT) dengan kepercayaan 95\% dan 99\% (Steel dan Torrie, 1993)

Ikan Nila dipelihara dalam keramba jaring apung (KJA) berukuran $1 \times 1 \times 1,2 \mathrm{~m}$ dengan padat penebaran 50 ekor per KJA. Sebelum digunakan untuk percobaan ikan terlebih dahulu diaklimasi selama tiga hari untuk penyesuaian terhadap kondisi lingkungan.

Ikan Nila diberi pakan sebesar 3\% dari total bobot ikan dan diberikan sebanyak dua kali yaitu pada pagi hari dan sore hari. Pakan yang diberikan sebelumnya diberikan $\mathrm{MEP}^{+}$ dengan cara menyemprotkan campuran $\mathrm{MEP}^{+}$sebanyak $1 \mathrm{cc}$ dan air $300 \mathrm{ml}$ pada $1 \mathrm{~kg}$ pelet dan dibiarkan 10 menit sambil diratakan agar terserap merata.

Ikan nila diambil sebanyak 2-4 ekor secara acak kemudian dimasukkan ke dalam plastik aseptis dan disimpan dalam icebox untuk dihitung jumlah BAL dalam usus ikan di Laboratorium Fakultas Biologi Unsoed. Ikan diambil ususnya secara aseptis sebanyak $1 \mathrm{~g}$, kemudian di maserasi dengan menggunakan mortal dan pestle dan dilakukan pengenceran bertingkat sampai 10-4. Dua pengenceran terkhir di platting duplo secara speard plate $(0,1 \mathrm{ml})$ ke dalam media MRSA lalu diratakan dengan drugalsky. Hasil platting diinkubasi $2 \times 24$ jam pada suhu $30^{\circ} \mathrm{C}$.

Cawan petri hasil isolasi dari sampel usus ikan yang ditumbuhi bakteri asam laktat diamati bentuk morfologi koloninya dan dihitung jumlah koloni yang tumbuh secara SPC (Standard Plate Count). Satuan untuk bakteri asam laktat usus ikan dengan satuan CFU's/ml. Pengenceran yang digunakan secara duplo ( 2 cawan petri).

\section{HASIL DAN PEMBAHASAN}

Berdasarkan hasil pengamatan populasi BAL pada usus ikan nila yang diberi pakan fermentasi limbah pertanian dengan suplemen enceng gondok dan probiotik diperoleh hasil yang disajikan pada Gambar 1. Berdasarkan Gambar 1 kepadatan bakteri asam laktat selama pengamatan diperoleh jumlah berkisar antara 3,5 x $10^{3}$ sampai dengan 6,33 x $10^{6}$ CFU.g- $^{-1}$. Kepadatan bakteri asam laktat pada perlakuan A,B,C,D berkisar antara 5 sampai dengan $6 \times 10^{6} \mathrm{CFU}^{-1}$ dan pada perlakuaan E sebesar $3 \times 10^{3}$ CFU.g-1. Pada pengamatan minggu ke-2 kepadatan bakteri asam laktat tertinggi pada perlakuan $C$ yaitu $6,13 \times 10^{6}$ CFU.g $^{-1}$, sedangkan pada pengamatan

minggu ke- 4 dan ke- 6 kepadatan bakteri asam laktat tertinggi pada perlakuan B sebesar $6,33 \times 10^{6}$ dan D sebesar 6,1 x $10^{6}$ CFU.g $^{-1}$.

Kepadatan bakteri asam laktat usus ikan nila pada masing-masing perlakuan selama 6 minggu penelitian diuji statistik menggunakan uji $\mathrm{F}$ atau ANOVA transformasi dalam logaritma. Hasil perhitungan uji $\mathrm{F}$ tersaji pada tabel berikut (Tabel 1).

Hasil perhitungan uji $\mathrm{F}$ diketahui bahwa pertumbuhan BAL pada usus ikan yang diberi pakan fermentasi limbah pertanian dengan suplemen enceng gondok dan probiotik $\mathrm{MEP}^{+}$(perlakuan $\mathrm{A}, \mathrm{B}, \mathrm{C}, \mathrm{D}$ ) dan pakan komersil (perlakuan E) menunjukkan perberbedaan hasil yang sangat nyata. Hal ini ditunjukkan dengan nilai $\mathrm{F}$ hitung $>\mathrm{F}$ tabel 0,01 . Dengan kata lain pemberian pakan fermentasi limbah pertanian dengan suplemen enceng gondok dan probiotik $\mathrm{MEP}^{+}$berpengaruh terhadap populasi bakteri asam laktat pada usus ikan nila. Bakteri asam laktat yang ada di dalam usus ikan mampu menyeimbangkan mikroba saluran pencernaan yang dapat meningkatkan daya cerna pakan dalam usus ikan dengan cara mengubah karbohidrat melalui serangkaian enzimatik menjadi asam laktat yang dapat menurunkan $\mathrm{pH}$, sehingga merangsang produksi enzim endogenous untuk meningkatkan penyerapan nutrisi, dan konsumsi pakan (Samadi (2002) dalam Arief, et al. (2008). Hasil uji lanjut BNT menunjukkan bahwa populasi BAL pada pemberian pakan fermentasi limbah pertanian dengan suplemen enceng gondok dan $\mathrm{MEP}^{+}$perlakuan $\mathrm{A}, \mathrm{B}, \mathrm{C}, \mathrm{D}$ menghasilkan perbedaan hasil yang sangat nyata dengan perlakuan $\mathrm{E}$, hal ini dikarenakan nilai selisih rata-rata antara perlakuan $A, B, C, D$ dengan perlakuan E lebih besar dari nilai BNT 1\% $(0,06)$. Perlakuan A menunjukkan perbedaan hasil yang nyata terhadap perlakuan $\mathrm{C}$ dan $\mathrm{D}$, hal tersebut dikarenakan nilai selisih rata-rata antara perlakuan A dengan perlakuan C, D lebih besar dari nilai BNT 5\% namun lebih kecil dari nilai BNT 1\% (0,04). Pada perlakuan B menunjukkan hasil yang tidak berbeda dengan perlakuan C dan D. Hal serupa juga terlihat pada perlakuan A bila dibandingkan dengan perlakuan $B$, dan perlakuan $\mathrm{C}$ dibandingkan perlakuan $\mathrm{D}$. Hal ini dikarenakan pada perlakuan tersebut selisih nilai rata-rata lebih kecil dari BNT 5\%.

Hasil perhitungan jumlah kepadatan bakteri asam laktat pada usus ikan Nila dengan perlakuan pemberian pakan fermentasi limbah pertanian dengan suplemen enceng gondok dan $\mathrm{MEP}^{+}$ menunjukkan bahwa pada perlakuan pemberian pakan fermentasi limbah pertanian dengan suplemen enceng gondok 10\% + probiotik $\mathrm{MEP}^{+}$(perlakuan C) 
memberikan hasil yang paling baik yaitu dengan nilai rata-rata populasi bakteri sebesar 5,84 x $10^{6} \mathrm{CFU} / \mathrm{g}$, diikuti oleh perlakuan $\mathrm{D}, \mathrm{B}$, dan $\mathrm{A}$, hal ini dikarenakan pada pakan perlakuan $A, B, C, D$ setelah difermentasi kandungan protein kasar tinggi dan adanya penambahan probiotik $\mathrm{MEP}^{+}$. Kepadatan BAL akan meningkat jika dalam substrat mengandung nutrisi yang cukup. Menurut Rachman (1989), kepadatan BAL akan meningkat apabila BAL tersebut memanfaatkan nutrisi dalam jumlah yang cukup. Pemberian probiotik akan meningkatkan efektivitas mikroba usus yang akhirnya dapat meningkatkan pertumbuhan dan perkembangan ikan melalui peningkatan daya cerna dalam sistem pencernaan ikan. Hal ini sesuai dengan pernyataan Tangko, et al., (2007) probiotik yang berisi mikroba pengurai bila ditambahkan kedalam pakan dapat meningkatkan daya cerna pakan dalam usus ikan nila. Perlakuan E merupakan perlakuan dengan hasil kepadatan bakteri asam laktat terendah. Hal ini karena pada perlakuan E tidak ada penambahan probiotik $\mathrm{MEP}^{+}$, sehingga bakteri asam laktat yang diperoleh merupakan bakteri asam laktat yang hanya berasal dari dalam saluran pencernaan ikan.

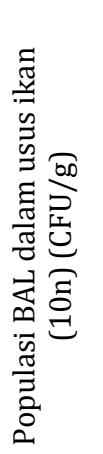

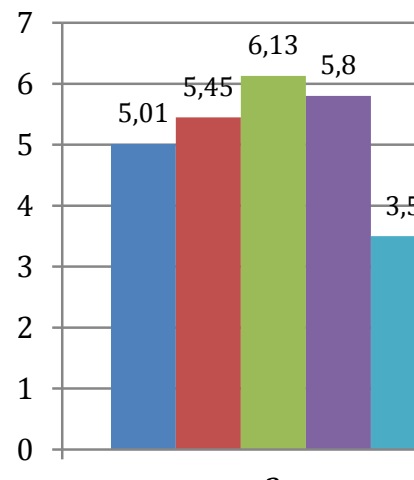

2
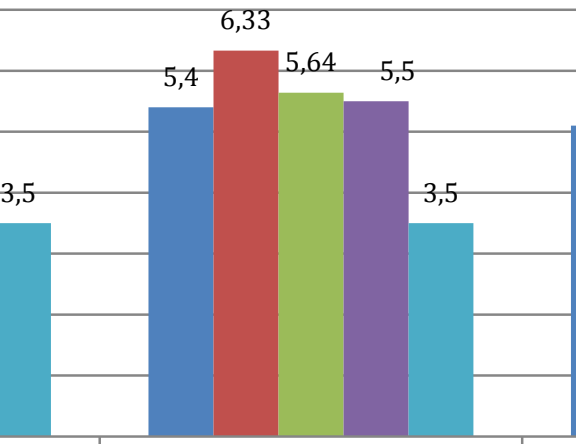

4

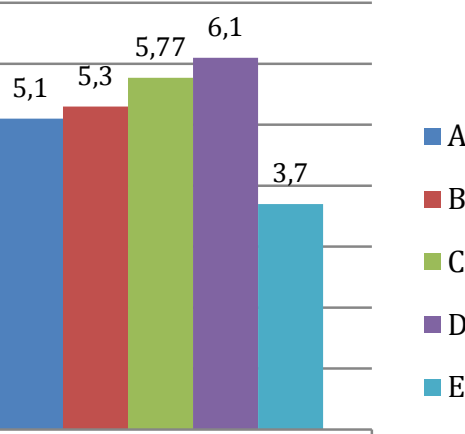

6

Minggu ke-

Gambar 1. Histogram populasi BAL (CFU/g) pada usus ikan Nila masing-masing peralakuan pada tiap pengambilan sampel selama 6 minggu penelitian.

Keterangan :

A : Usus sampel ikan dengan pemberian pakan fermentasi (kandungan suplemen enceng gondok $0 \%$ dan penambahan $\mathrm{MEP}^{+}$)

$\mathrm{B}$ : Usus sampel ikan dengan pemberian pakan fermentasi (kandungan suplemen enceng gondok $5 \%$ dan penambahan $\mathrm{MEP}^{+}$)

C : Usus sampel ikan dengan pemberian pakan fermentasi (kandungan suplemen enceng gondok $10 \%$ dan penambahan $\mathrm{MEP}^{+}$)

D : Usus sampel ikan dengan pemberian pakan fermentasi (kandungan suplemen enceng gondok $15 \%$ dan penambahan MEP+)

E : Usus sampel ikan dengan pemberian pakan komersial (tanpa penambahan $\mathrm{MEP}^{+}$)

Tabel 1. Hasil sidik ragam (uji F) pengaruh beberapa perlakuan pemberian pakan fermentasi limbah pertanian dengan suplemen enceng gondok dan probiotik terhadap populasi bakteri asam laktat usus ikan nila.

\begin{tabular}{ccccccc}
\hline Sumber & Derajat & Jumlah & Kuadrat & F & & F Tabel \\
Variasi & Bebas & Kuadrat & Tengah & Hitung & 0.05 & 0.01 \\
\hline Perlakuan & 4 & 24.5686 & 6.1422 & $9213.2359^{* *}$ & 3.48 & 5.99 \\
Galat & 10 & 0.0067 & 0.0007 & & & KK $=0.423 \%$ \\
Total & 14 & 24.5753 & & & & \\
\hline
\end{tabular}

Keterangan :** = Berebeda sangat nyata

Tabel 2. Uji BNT terhadap pertumbuhan bakteri asam laktat antar perlakuan pemberian pakan fermentasi limbah pertanian dengan suplemen enceng gondok dan probiotik

\begin{tabular}{crrrr}
\hline Perlakuan & \multicolumn{1}{c}{ A } & B & C & D \\
\cline { 2 - 5 } & 6.713 & 6.753 & 6.767 & 3.763 \\
\hline E (3.550) & $3.163^{* *}$ & $3.203^{* *}$ & $3.213^{* *}$ & \\
D (6.763) & $0.050^{*}$ & $0.010^{\mathrm{ns}}$ & $0.003^{\mathrm{ns}}$ & \\
C (6.767) & $0.053^{*}$ & $0.013^{\mathrm{ns}}$ & & \\
B (6.753) & $0.040^{\mathrm{ns}}$ & & & \\
A (6.713) & & & & \\
\hline
\end{tabular}

Keterangan : ${ }^{*}=$ berbeda nyata, ${ }^{* *}=$ berbeda sangat nyata, $\mathrm{ns}=$ tidak berbeda

Bakteri asam laktat adalah kelompok bakteri yang mampu mengubah karbohidrat (glukosa) menjadi asam laktat. Efek bakterisidal dari asam laktat dapat menyeimbangkan mikroba saluran cerna selain itu juga dapat menurunkan $\mathrm{pH}$ lingkungan menjadi 3 sampai 4,5 sehingga pertumbuhan bakteri lain termasuk bakteri pembusuk akan terhambat (Amin dan Leksono, 2001 dalam Rostini, 2007). Menurut Hadioetomo (1993), kelompok mikroba asam laktat apabila berada dalam saluran pencernaan inang (internal) berperan sebagai probiotik dan apabila berada pada lingkungan sekitar (eksternal) berperan aktif sebagai dekomposer, sehingga pemberian probiotik 
memberikan dampak yang baik karena tidak mengganggu keseimbangan lingkungan.

Pemberian probiotik pada pakan akan meningkatkan daya cerna pakan dalam saluran pencernaan ikan sehingga proses absorbsi sari makanan menjadi lebih efektif dan efisien. Hal ini dikarenakan mikroba dari probiotik menghasilkan enzim-enzim ekstraseluler, di samping juga dieksekresikan enzim-enzim ekstraseluler dari flora normal mikroba maupun dari kelenjar pencernaan inang. Oleh karena itu proses pencernaan menjadi lebih cepat menghasilkan molekul-molekul sederhana dalam jumlah yang lebih banyak (Sukanto dan Sutardi, 2008). Dengan demikian, adanya probiotik dalam saluran pencernaan berperan aktif dalam meningkatkan kecernaan pakan.

Pertumbuhan mikroba juga dipengaruhi oleh kandungan nutrien substrat antara lain: unsur makro dan unsur mikro. Unsur makro meliputi karbon, nitrogen, phospat, kalium, magnesium, dan sulfur, sedangkan unsur mikro seperti besi, seng, tembaga, mangan, dan vitamin kadar air. Iriyanti et al. (2002) menjelaskan bahwa, mikroorganisme yang berada di dalam usus membutuhkan nutrien untuk tumbuh dan berkembang biak, nutrien tersebut didapatkan dari pakan yang masuk ke dalam tubuh inang. Pada pakan dengan nutrien cukup, mikroorganisme akan tumbuh dan berkembang dengan baik. Ringo dan Gatesoupe (1998) menerangkan, Lactobacillus memerlukan nutrisi yang kompleks meliputi: karbohidrat, asam amino, peptida, asam lemak atau ester asam lemak, derivat asam nukleat, dan vitamin.

Pakan fermentatif berbahan enceng gondok pada dasarnya mengandung protein nabati. Protein tersebut lebih sukar dicerna oleh ikan yang termasuk dalam golongan ikan karnivora karena bahan tersebut terbungkus oleh dinding selulosa. Menurut Perez et al. (2002), selulosa merupakan komponen utama pada jaringan tumbuhan dan merupakan polimer glukosa tidak bercabang terdiri atas unit-unit D-glukosa yang dihubungkan oleh ikatan $\beta$-1,4-glikosidik membentuk molekul selobiosa.

Proses fermentasi limbah organik oleh bakteri dapat terjadi karena adanya aktivitas enzim. Menurut Gerhartz (1990) dalam Anindyawati (2010) selulase adalah enzim kompleks yang memotong secara bertahap rantai selulosa menjadi glukosa. Enzim endoglukanase dan silanase aktif dalam mendegradasi selulosa dan hemiselulosa (Tarmidi dan Hidayat, 2004). Bakteri selulolitik dapat menghasilkan enzim selulase yang dapat mendegradasi senyawa selulosa limbah organik. Bakteri penghidrolisis Celullomonas cellasea yang terdapat pada probiotik $\mathrm{MEP}^{+}$mampu menghidrolisis polisakarida menjadi oligosakarida dan akan dihidrolisis lagi sampai tingkat monosakarida (glukosa) sehingga mudah dicerna dalam sistem pencernaan ikan.

Menurut Rohmantika (2004) glukosa merupakan substrat utama yang dirombak dalam proses fermentasi dan akan menghasilkan asam laktat. Glukosa yang terbentuk dari hasil perombakan selulosa, akan dimanfaatkan oleh Lactobacillus sebagai substrat yang merupakan sumber utama karbon dan energinya. Schlegel dan Schmidt (1985) menjelaskan bahwa, glukosa yang telah terbentuk masuk ke dalam sel bakteri melalui translokasi gugus dan transport aktif. Semakin banyak gula yang dikonsumsi dalam metabolisme, maka terjadi penurunan $\mathrm{pH}$ dalam medium fermentasi, semakin menurun kadar gula reduksinya, dan semakin banyak asam laktat yang dihasilkan.

Faktor lain yang mempengaruhi pertumbuhan ikan selain dari kepadatan BAL yaitu kondisi fisikakimia perairan budidaya. Kualitas air yang baik mendorong kesehatan ikan dalam budidaya. Hasil pengukuran fisika-kimia perairan dapat dilihat pada suhu perairan kolam budidaya berkisar antara 27$28^{\circ} \mathrm{C}$. Menurut Ghufran et al. (2007) suhu optimal untuk budidaya ikan nila (Oreochromis niloticus) berkisar antara $25-33^{\circ} \mathrm{C}$. Suhu dapat mempengaruhi kehidupan dan pertumbuhan biota air secara tidak langsung, yaitu berpengaruh terhadap kelarutan oksigen dalam air. Kondisi pH air pada setiap perlakuan adalah 7. Ghufran et al. (2007) menyebutkan bahwa ikan nila dapat hidup normal pada air dengan $\mathrm{pH}$ 7-9. Peran $\mathrm{pH}$ dalam perairan dapat mempengaruhi kesuburan perairan karena mempengaruhi kehidupan jasad renik.

Pengukuran oksigen terlarut di perairan didapatkan nilai 3,58 mg/l. Nilainya masih dalam batas yang memenuhi baku mutu jika dibandingkan berdasarkan PP No.82 tahun 2001 nilai oksigen terlarut untuk budidaya perikanan yang baik batas minimumnya yaitu $3 \mathrm{mg} / \mathrm{l}$. Ikan merupakan makhluk air yang memerlukan oksigen terbesar, sedangkan bakteri memerlukan oksigen terkecil.

Kondisi total amoniak sebagai $\mathrm{N}\left(\mathrm{N}-\mathrm{NH}_{3}\right)$ pada setiap perlakuan rata-rata berkisar antara $0,6523-$ $0,7065 \mathrm{mg} / \mathrm{l}$ dan standar deviasinya $\pm 0,0281 \mathrm{mg} / \mathrm{l}$. Konsentrasi amoniak tersebut jauh di atas konsentrasi optimum untuk budidaya perikanan. Menurut Widyastuti et al. (2010) kadar amoniak yang baik untuk budidaya perikanan tidak boleh melebihi 0,1 mg/l, sehingga kadar amoniak yang diperoleh berada dalam batas yang perlu mendapat perhatian. Tingginya kadar amoniak dapat terjadi karena terdapatnya bahan organik dalam air. Menurut Riyadi (2006) amoniak yang tinggi merupakan indikasi adanya pencemaran bahan organik yang berasal dari limbah domestik, industri, dan limpasan dari aliran air yang masuk selain dari sisa pakan. Hasil pengukuran fisika-kimia perairan kolam budidaya berdasarkan uraian di atas dapat dikatan sebagai kualitas yang masih memenuhi 
syarat untuk pertumbuhan dan peningkatan jumlah bakteri asam laktat serta budidaya ikan nila.

\section{KE S I M P U L A N}

Berdasarkan hasil dan pembahasan sebelumnya dapat diambil kesimpulan sebagai berikut :

1. Pemberian pakan fermentasi limbah pertanian dengan suplemen enceng gondok dan probitik $\mathrm{MEP}^{+}$mampu meningkatkan populasi BAL usus ikan nila.

2. Pakan fermentasi limbah pertanian dengan suplemen enceng gondok sebanyak 10\% dan probiotik $\mathrm{MEP}^{+}$memberikan kepadatan populasi BAL tertinggi dengan rata-rata populasi BAL sebesar 5,85 x $10^{6} \mathrm{CFU} / \mathrm{g}$.

\section{DAFTAR REFERENSI}

Anindyawati T. 2010. Potensi selulase dalam mendegradasi lignoselulosa limbah pertanian untuk pupuk organik. Jurnal Berita Selulosa. 45(2): 70-77.

Arief M, Kusumaningsih E, Rahardja BS. 2008. Kandungan protein kasar dan serat kasar pada pakan buatan yang difermentasi dengan probiotik. Berkala Ilmiah Perikanan. 3(2): 1-3.

Bautista M. 1981. Food Formulation and feeding. Tigbauan Ho: Training and Extention Aquaculture Department; Southern Asian Fisheries Development Center.

Ghufran MH, Kordi K, Andi BT. 2007. Pengelolaan kualitas air dalam budidaya perairan. Jakarta: Penerbit Rineka Cipta.

Hadioetomo RS. 1993. Mikrobiologi dasar dalam praktek. teknik dan prosedur dasar laboratorium. Jakarta: PT. Gramedia.

Irianto A. 2003. Probiotik akuakultur. Yogyakarta: Gajah Mada University Press.

Iriyanti N, Aris ER, Rahayu S. 2002. Suplementasi kultur Lactobacillus sp. dan Bacillus sp. sebagai probiotik dan antibiotik dalam ransum terhadap peningkatan kecernaan nutrien ayam broiler. Purwokerto: Fakultas Peternakan, Universitas Jenderal Soedirman; Laporan Hasil Penelitian.

Marlina N, Askar S. 2001. Nilai gizi eceng gondok dan pemanfaatan sebagai pakan ternak non ruminansia. Bogor: Balai Penelitian Ternak.
Pato. 2003. Potensi bakteri asam laktat yang diidolasi dari dadih untuk menurunkan resiko penyakit kanker. Pekanbaru: Universitas Riau.

Perez J, Dorado JM, Rubia T, Martinez J. 2002. Biodegradation and biological treatments of cellulose, hemicellulose and lignin: an overview. Int. Microbiology. 5: 53-63.

Rachman A. 1989. Pengantar teknologi fermentasi. Pusat Antar Universitas Pangan dan Gizi Institut Pertanian Bogor : 88-92.

Ringo E, Gatesoupe FJ. 1998. Lactic acid bacteria in fish: a review. Aquaculture. 160: 177-203.

Riyadi A. 2006. Kajian kualitas air waduk Tirta Shinta di Kotabumi Lampung. Journal Hidrosfir.1(2): 75-82.

Rohmantika. 2004. Kemampuan Lactobacillus plantarum dan Streptococcus faecalis dengan penambahan sumber karbohidrat kulit umbi ubi kayu terhadap produksi asam laktat silase ikan [skripsi]. Fakultas Biologi, Universitas Jenderal Soedirman-Purwokerto.

Rostini I. 2007. Peranan bakteri asam laktat (Lactobacillus plantarum) terhadap masa simpan filet nila merah pada suhu rendah [karya Ilmiah]. Fakultas Perikanan dan Ilmu Kelautan, Universitas Padjadjaran-Jatinagor.

Schlegel HG, Schmidt K. 1994. Mikrobiologi umum [diterjemahkan oleh Baskoro RMT]. Edisi Keenam. Yogyakarta: Gadjah Mada University Press.

Sukanto, Sutardi TR. 2008. Pengembangan budidaya ayam broiler secara nonkonvensional melalui pemberian probiotik $\mathrm{MEP}^{+}$. Jurnal Pengembangan Penerapan Teknologi. VI(1): 397-409.

Steel RGD, Torrie JH. 1993. Prinsip dan Prosedur Statistika Suatu pendekatan Biometrik [diterjemahan oleh Sumantri B]. Edisi kedua. Jakarta: Gramedia Pustaka Utama.

Tangko AM, Mansyur A, Reski. 2007. penggunaan probiotik pada pakan pembesaran ikan bandeng dalam KJA di laut. Jurnal Riset Akuakultur. II(I): 33-34.

Tarmidi AR, Hidayat R. 2004. Peningkatan kualitas pakan serat ampas tebu melalui fermentasi dengan jamur tiram putih (Pleurotus ostreatus). Jurnal Bionatura. 6(2):197-204.

Widyastuti E, Sukanto, Rukayah S. 2010. Upaya pelestarian waduk dengan budidaya keramba jaring apung ramah lingkungan. Prosiding Seminar Nasional Limnologi $\mathrm{V}$; Limnotek; Bogor.

Yulianti P, Kadarini T, Rusmaedi, Subandiyah S. 2003. Pengaruh padat penebaran terhadap penebaran dan pertumbuhan dan sintasan dederan ikan nila GIFT (Oreochromis niloticus) di kolam. Jurnal Iktiologi Indonesia.3(2):63-66. 